'Department of Cardiology, Izmir Katip Celebi University, Faculty of Medicine, Ataturk Training and Reseasch Hospital, Izmir, Turkey ${ }^{2}$ Department of Pathology, Izmir Katip Celebi University, Faculty of Medicine, Ataturk Training and Reseasch Hospital, Izmir, Turkey

Cite this article as: Özdemir E, Karaca M, Çakalağaoğlu Ünay F. A Case Report of the Recurrence of a Rare Cardiac Low-Grade Fibromyxoid Sarcoma and Mortality. Bosphorus Med J 2020;7(1):28-31.

Received: 29.07.2019 Accepted: 02.12.2019

Correspondence:

Dr. Emre Özdemir.

İzmir Katip Çelebi Üniversitesi, Atatürk Eğitim ve Araştırma Hastanesi Tıp Fakültesi, Kardiyoloji Anabilim Dalı, İmir, Turkey

\title{
A Case Report of the Recurrence of a Rare Cardiac Low-Grade Fibromyxoid Sarcoma and Mortality
}

\author{
Nadir bir Düşük-grade Fibromiksoyid Sarkom \\ Rekurrensi ve Mortalitesine Ait Vaka Sunumu
}

(1] Emre Özdemir,' (D) Mustafa Karaca,' (10 Fülya Çakalağaoğlu Ünay²

\section{ABSTRACT}

As the majority of cardiac tumors are benign, malignant tumors may be easily missed. The case presented here was a female with complaints of dyspnea who was diagnosed with a left atrial mass of regular shape. After surgical excision with a pre-diagnosis of hemangioendothelioma in the frozen-section, the operation finished with mitral valve replacement. The pathological diagnosis from the immunohistochemical examination was of low-grade fibromyxoid-sarcoma. At three months postoperatively, the patient was re-hospitalized with dyspnea. Echocardiography detected a giant mass in the left atrium, $45 \times 24 \mathrm{~mm}$ in size. The hemodynamic collapse resulted in mortality. The idea that cardiac tumors are more frequently benign causes malignant masses to be overlooked. With the perspective of an internal medicine specialist, the characteristics of each cardiac tumor should be evaluated with both clinical and imaging methods before the cardiac surgery.

Keywords: Cardiac tumor; fibromyxoid sarcoma; myxofibrosarcoma.

\section{ÖZET}

Kardiyak tümörlerin çoğunun iyi huylu olması nedenli, malign tümorler gözden kaçabilmektedir. Bu yazıda, dispne yakınması ile, sol atriyumda düzgün şekilli kitle tanısı olan, bir bayan hastanın sunumu yapılmıştır. Cerrahi eksizyondan sonra, frozen-kesit bakıda, ön tanı olarak hemanjiyoendotelyoma tanısı alan hastanın, operasyonu mitral kapak replasmasnı ile sonlandırılmıştır. Takibinde patolojik tanı olarak immunohistokimyasal bakı sonrası düşük-grade fibromiksoyid sarkom, operasyondan üç ay sonra tekrar dispne ile hospitalize edilmiştir. Ekokardiyografide aynı bölgede, tüm atriyumu dolduran, 45 × 24 mm boyutlu dev kitle saptanmıştır. Hasta takibinde hemaodinamik kolabs ile kaybedilmiştir. Kardiyak tümörlerin daha sık iyi huylu olduğu fikri, malign kitlelerin gözden kaçmasına neden olabilir. Vakaya bir dahiliye uzmanının bakış açısıyla, her kalp tümörünün - benign-malign olma lehineözellikleri, kalp ameliyatından önce hem klinik hem de görüntüleme yöntemleri ile değerlendirilmesi bu sorunu engelleyebilir.

Anahtar sözcükler: Kardiyak tümör; fibromiksoid sarkom; miksofibrosarkom.

Tis he incidence of cardiac tumors has been reported as $0.02 \%$ in a large autopsy series. [1] The incidence of primary cardiac tumors is $1 / 1000$ at autopsy and 1.5/1000 on echocardiography, but general population data are not well-known. ${ }^{[1]}$ It has been stated that $75 \%$ of cardiac tumors are benign, and 25\% are ma- lignant forms. Metastatic tumors of the heart are 30 times more common than primary tumors. ${ }^{[1]}$ The case presented here is a patient with a rare sarcoma of the heart, a low-grade fibromyxoid sarcoma (LGFMS), which resulted in mortality four months after the pathological diagnosis. 


\section{Case Report}

A 72-year-old female presented at the cardiology with dyspnea. A systolic murmur was detected in the mitral focus on physical examination. Transthoracic-echocardiography (TTE) revealed a $4.5 \times 2.4 \mathrm{~cm}$ (Fig. 1a) regularly-shaped tumoral mass, on the left atrial side of the posterior mitral valve (Fig. 1b). This tumoral mass caused a moderate mitral stenosis with a $1.4 \mathrm{~cm}^{2}$ valve area (Fig. 1c). Clinical prediagnosis was myxoma and surgical excision was decided after cardiovascular surgery, cardiology and anesthesia
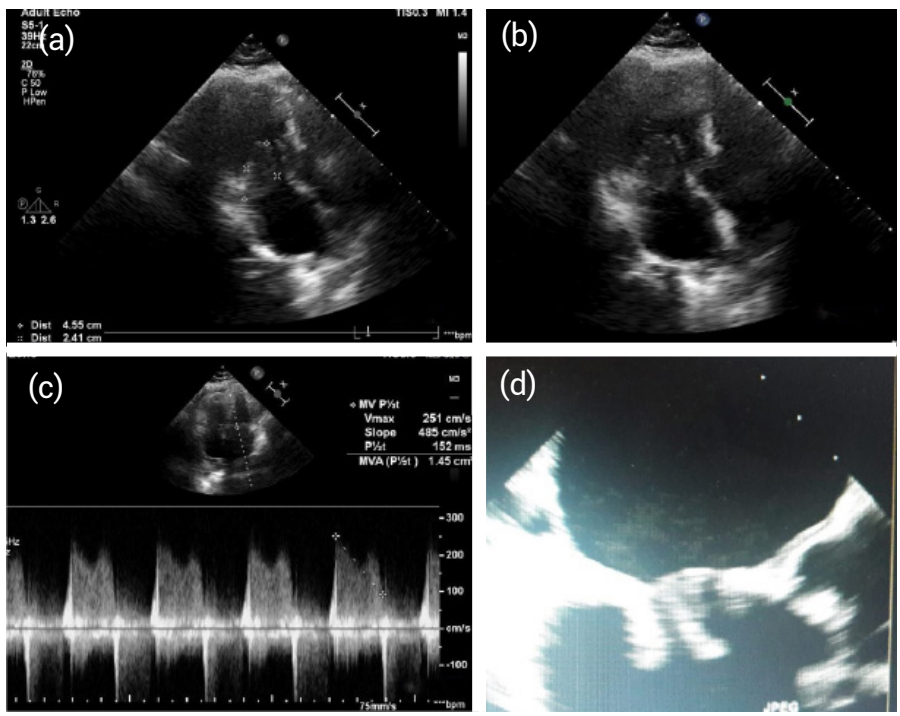

Figure 1. Dimensions are measured as $45 \times 24 \mathrm{~mm}$ (a); regularly-shaped tumoral mass is on the left atrial side of the posterior mitral valve (b); there is a moderate mitral stenosis with a $1.4 \mathrm{~cm}^{2}$ valve are due to tumor (c); the echocardiographic view of a bioprosthetic mitral valve (d).
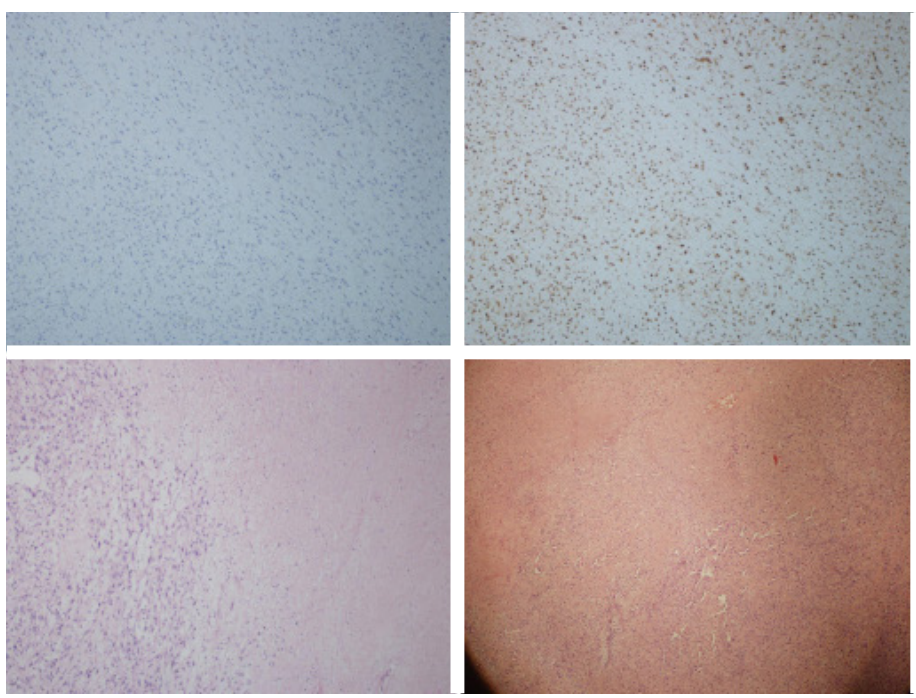

Figure 2. Histopathological and immunohistological preparations.
-

(heart team) consultation. The tumoral mass was extracted together with the mitral valve because of valve invasion of the tumor. With the pre-diagnosis of hemangioendothelioma in the frozen-section, the operation was successfully finished with mitral valve replacement (Fig. 1d). Coumadin and $100 \mathrm{mg}$ acetylsalicylic acid treatment were started with effective INR value. All operation material was sent to the pathology department. The tumor was seen to continue through the surgical margins on the paraffin sections. Immunohistochemical examination showed that the tumor cells were immunopositive for vimentin, focal positive for smooth-muscle actin, CD34, CD31, and immune negative for epithelial membrane antigen, CD68, myogenicdifferentiation-1, desmin. The pathological diagnosis was made of LGFMS (Fig. 2). Computed tomography (CT) was applied to the patient, but no other tumor was observed. The patient was referred to oncology after this diagnosis. Chemotherapy or radiotherapy could not be applied due to the refusal of treatment of the patient and relatives. At third-months postoperatively, the patient presented at the Emergency Department, again suffering from dyspnea. The patient was admitted to the intensive care unit, and a diuretic infusion was started. The TTE and transesophageal-echocardiography (TEE) were performed, and a giant mass with cystic areas was observed to fill the left atrium completely and was disrupting valve movements (Fig. 3). After consultation with the cardiac team on the basis of the new findings, it was decided to re-operate when hemodynamic stabilization was obtained. On the 10th day of hospitalization, the patient was exitus due to hypotension despite inotrope infusion.
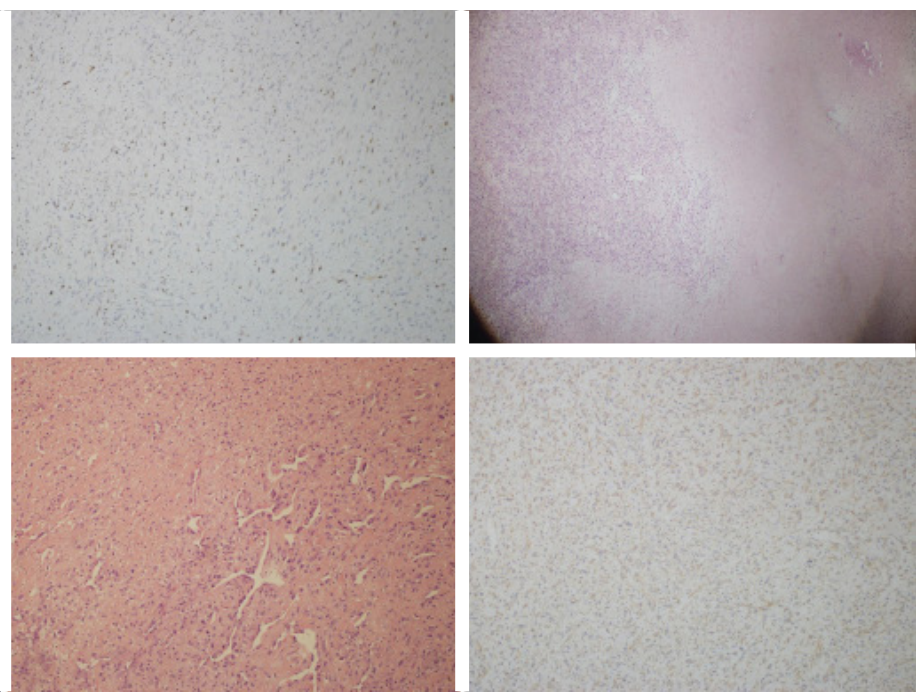


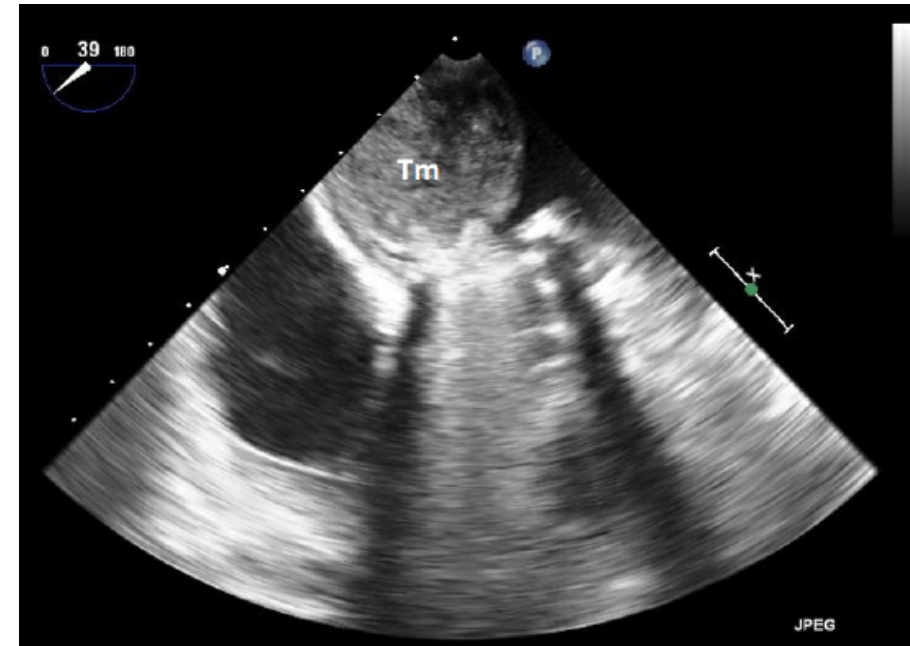

Figure 3. There is a huge tumoral mass that totally filled the left atrium.

\section{Discussion}

Primary cardiac tumors are rare, with $0.3 \%-0.7 \%$ incidence of all recorded cardiac tumors. Metastasic tumors are 30 times more common. ${ }^{[2]}$ Of the primary tumors, 2/3 is benign, and myxoma is the most common type. The remaining third of primary tumors are malignant, of which $2 / 3$ are sarcomas. [1] The most common sarcoma of the heart is angiosarcoma, and primary cardiac myxofibrosarcoma is much rarer. In 2012, Wang et al. ${ }^{[3]}$ reported a case of a 42-year-old male, and only 17 cases were found since 1963 in their literature research. This tumor, which has been described in recent years, is mostly seen in young adults and is mostly located in deep soft tissues. ${ }^{[4]}$ In contrast, the current case was middle-aged, and the mass was located in the heart, thereby making this case one of the known rare patients.

Macroscopically, the tumor is well-circumscribed and has a cross-sectional face that can vary between a fibrous and myxoid appearance. Microscopically the tumor surrounds a pseudo-capsule. However, focal infiltration can be detected in surrounding soft tissues. The tumor consists of smooth, fibroblastic spindle cells that show a fibromyxoid growthpattern. ${ }^{[5]}$ It may be confused with many other soft tissue tumors. ${ }^{[6]}$ In accordance with these data, the pre-diagnosis in the current case was hemangioendothelioma on the frozensection, and the surgical section borders were not sufficient for total tumoral resection.

Low-grade fibromyxoidsarcoma ais detected predominantly in the left atrium, and less frequently, the tumor can invade the mitral valve. ${ }^{[3]}$ In the current case, the tumor was also on the left atrial side of the posterior mitral valve. Dyspnea is the most common symptom on presentation, as was seen in the current patient.

The main treatment is as much surgical resection of the tumor as possible, obtaining a negative limit of the surgical margin. Curative resection and adjuvant radiotherapy are recommended, but the long-term efficacy is not well known. ${ }^{[7]}$ Also, Reardon et al. ${ }^{[8]}$ reported a 30-day mortality rate of $9 \%$, with survival on the patient that had negative surgical margins.

As LGFMS is known to have high mortality and the late diagnosis of tumoral malignancy in the current case, rendered total resection of the tumor on re-operation technically challenging due to the functional importance of the heart and the difficulty of surgical access.

Early recurrence of LGFMS is not expected. According to this data, Wang et al. ${ }^{[9]}$ presented an LGFMS with a patient who developed a bone metastasis two years later and is still alive 26 months after the cardiac surgery. In our patient, recurrence in the same region was probably due to incomplete excision due to perioperative benign diagnosis and refusal of chemo-radiotherapy of the patient.

\section{Conclusion}

Due to the rare frequency of malignant cardiac tumors, cardiologists and cardiovascular surgeons have little experience in the clinical evaluation of cardiac malignancies. The idea that cardiac tumors are more frequently benign may cause malignant masses to be missed.

With the perspective of an internal medicine specialist, the characteristics of each cardiac tumor should be evaluated with both clinical and imaging methods, also if possible with transcatheter biopsy (especially for right heart originated tumors), before cardiac surgery. Furthermore, perioperative frozen-section evaluation by experienced pathologists may change the prognosis with a true diagnosis.

\section{Disclosures}

Informed consent: Written informed consent was obtained from the patient for the publication of the case report and the accompanying images.

Peer-review: Externally peer-reviewed.

Conflict of Interest: None declared.

Authorship Contributions: Concept - E.Ö.; Design - M.K.; Supervision - M.K.; Materials - F.Ç.Ü.; Data collection \&/or processing - E.Ö.; Literature search - E.Ö.; Writing - E.Ö. 


\section{References}

1. Basso C, Rizzo S, Valente M, Thiene G. Prevalence and pathology of primary cardiac tumors. Cardiovascular Medicine 2012;15:18-29.

2. Bisel HF, Wroblewski F, Ladue JS. Incidence and clinical manifestations of cardiac metastases. J Am Med Assoc 1953;153:7125.

3. Wang JG, Li YJ, Liu H, Zhao P. Primary cardiac myxofibrosarcoma: a case report and review of the literature. Tumori 2012;98:165e-8e.

4. Goodlad JR, Mentzel T, Fletcher CD. Low grade fibromyxoid sarcoma: clinicopathological analysis of eleven new cases in support of a distinct entity. Histopathology 1995;26:229-37.

5. Ninfo VV, Montesco MC. Myxoid tumors of soft tissues: a challenging pathological diagnosis. Adv Clin Path 1998;2:101-15.

6. Kösem M. Low-Grade Fibromyxsoid Sarcoma: A Report Of 3 Cases. Turk Patoloji Derg 2002;18:68-70.

7. Lam YL, Ho WY, Ng TP, Kan A, Shek TW. A sarcoma of 23 years' duration: symptom duration is not a reliable parameter to exclude malignancy. Hong Kong Med J 2012;18:250-2.

8. Reardon MJ. Malignant tumor overview. Methodist Debakey Cardiovasc J 2010;6:35-7.

9. Wang JG, Li YJ, Liu H, Zhao P. Primary cardiac myxofibrosarcoma: a case report and review of the literature. Tumori Journal 2012;98:e165-8. 